\title{
'The scourges of Homer'. Some remarks on the term Homeromastiges
}

\author{
Marta Fogagnolo
}

(University of Pisa)

\begin{abstract}

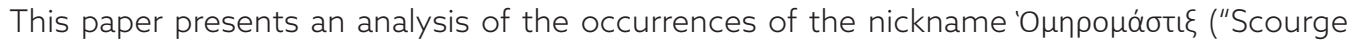
of Homer") in Greek and Latin literature. In the singular form, the term occurs exclusively in reference to Zoilus of Amphipolis, Homeric critic of the 4th century BC and author of Against

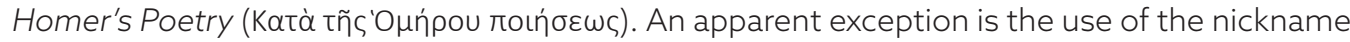
referring to Zenodotus of Ephesus, which seems to be due to a scholiast's misunderstanding of Luc. pro Im. 24. The term occurs in the plural form three times. Among these three occurrences, one (Eust. Od. 1.301.29-31 Stallbaum) can be perhaps compared to a fragment of Zoilus' Homeric exegesis (schol. Hdn. vel ex. II. 1.129a A), and as a result, it is possible to suggest

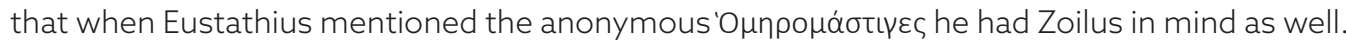

\section{Keywords}

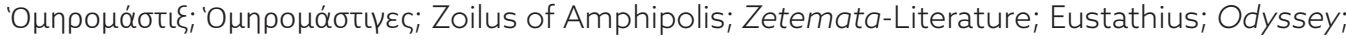
lliad; solecism 
It is widely recognized that the ancient literary tradition is based on Homer, and all subsequent Greek and Roman literature was undoubtedly influenced by the author of the Iliad and the Odyssey, which were perceived as the foundation of the ancient paideia. The birth of the great Alexandrian philology was closely linked to the need to safeguard, transmit and interpret especially (but not exclusively) the Homeric texts. Therefore, there are only few detractors of the poet, with the exception of occasional criticisms related to minor inconsistencies and contradictions in his poems. ${ }^{1}$ For, as Horace observes, even the great poet was sometimes caught napping, quandoque bonus dormitat Homerus (AP 359).

The most famous Homeri obtrectator is surely Zoilus of Amphipolis, who was a rhetorician, historian and Homeric exegete of the 4th century BC, contemporary of Plato

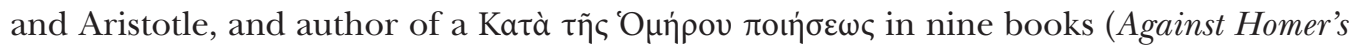
Poetry), where he raised punctual criticisms on specific passages of the Homeric poems. The context of Zoilus' exegesis is the so-called Zetemata-Literature, traces of which are preserved by the Homeric scholia in the form of questions and answers. ${ }^{2}$ Zoilus' criticism of Homer condemns the poet's lack of respect for physical and natural phenomena.

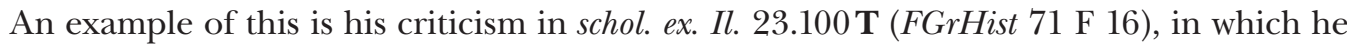
takes issue with Homer's portrayal of the soul's descent into Hades of $I l$. 23.100, as the natural direction of smoke is to rise from the ground upwards. He also criticizes inconsistencies in customs and behaviour, as in schol. D Il. 5.20 ZYQXABUILe (FGrHist $71 \mathrm{~F}$ 7), where he ridicules Idaeus' escape without horses and chariot, arguing that he would have been much more likely to save himself if he had used them. Some Homeric images are also the object of Zoilus' hyper-rational criticism, as in schol. ex. Il. 22.210b T (FGrHist 71 F 15), where he mocks the position of the Moirai weighed on Zeus' scales, wondering whether they were sitting or standing. ${ }^{3}$

However, it was not so much Zoilus' exegesis on the texts of Homeric poems (of which very little has been preserved, i.e. 19 fragments) that made him famous, rather the generous set of biographical and anecdotal information that circulated about him within classical literature. There are several anecdotes related to the punishments that were inflicted on him by kings, admirers of Homer, precisely because of his stance as a Homeric detractor. ${ }^{4}$ Adhering to a characteristic practice of ancient biographers, these biographical anecdotes were closely associated with the character of his literary output. For instance, various sources convey what was to be the nickname of the grammarian,

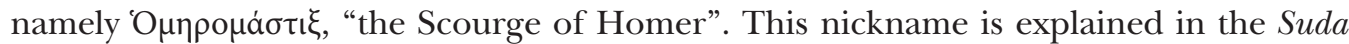

1 This is also characteristic of Alexandrian philologists: on Aristarchus see Schironi (2018: pp. 453-456).

2 On the Zetemata-Literatur, see Gudeman (1927: pp. 2515-2517); Erbse (1960: pp. 60-63); Gärtner (1978: pp. 2511, 2515-2517); Heath (2009: pp. 251-255); Novokhatko (2015: p. 47); Bouchard (2016: pp. 21-25); Schironi (2018: pp. 535-539)

3 On Zoilus, see Blass (1874: pp. 344-349); Friedländer (1895: pp. 29-46); Pilch (1924); Pfeiffer (1968: p. 70); Gärtner (1978: pp. 1549-1550); Matthaios (2009); Williams (2013); Regali (2015); Goulet-Cazé (2018: pp. 421-436); Mayhew (2019: pp. 5-6); Pavlova (2019); Novokhatko (2020: pp. 112-120). The analysis of this paper is based on the edition of Zoilus' grammatical fragments, on which I am currently working.

4 On the anecdotes on the Homeric critics, see Fraser (1970); Weiß (2019). 


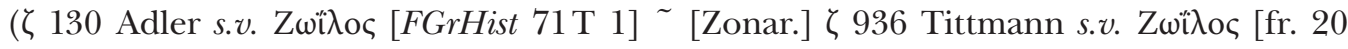

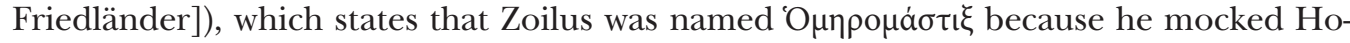

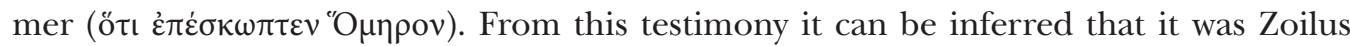
himself, rather than his work, that was termed $\mathrm{O} \mu \eta \rho \operatorname{cod}^{\circ} \sigma \mathrm{\tau} \xi$, as the relative pronoun ö clearly refers to the grammarian. This indicates that the hypothesis, formulated by sev-

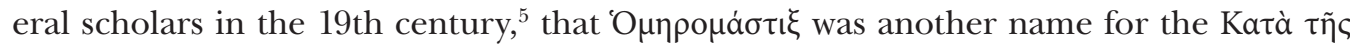

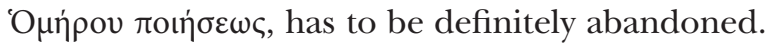

In this paper, the occurrences of the nickname $\mathrm{O} \mu \eta \rho \mu_{\alpha} \sigma \tau \tau \xi \xi$ will be analysed, showing that in the singular form it almost exclusively refers to Zoilus of Amphipolis. The paper will also focus on one of the rare occurrences of the term in the plural, where again it is perhaps possible to see a reference to this grammarian. Several sources ascribe the nickname to Zoilus: in addition to the Suda and the Lexicon of Pseudo-Zonaras, see also Vitr. Ar. 7 Praef. 8 (FGrHist $71 \mathrm{~T}$ 3), Gal. Meth.Med. 1.3 (fr. 13 Friedländer), schol. Porph. Il. 10.274 BF (FGrHist 71 F 9), Eust. Il. 2.3.13-29 Valk (fr. 27 Friedländer), Eust. Od. 1.321.44-322.1 Stallbaum (fr. 39 Friedländer), Tzetz. Exeg.Il. 3.13 (FGrHist 71T 2). An

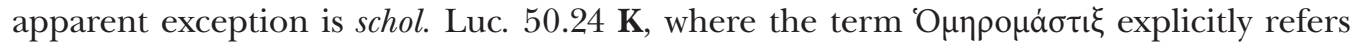
to the grammarian Zenodotus of Ephesus, who was called in this way for having marked spurious verses with the diacritical sign of the obelos and having athetized many of the Homeric verses.

schol. Luc. 50.24 ó $\mu \alpha \sigma \tau i \xi \alpha$ то

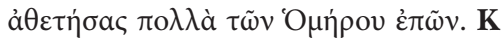

'the one who dares to whip-of the obeloi: Zenodotus is called Homeromastix since he placed the obeloi and athetized many of the Homeric verses.'

This is, however, only an apparent exception, as it is derived from the scholiast's misunderstanding of the text being commented upon, namely Lucian's Pro imaginibus (24):

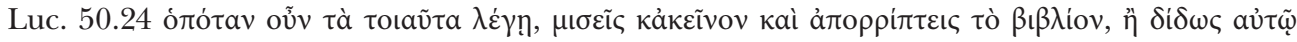

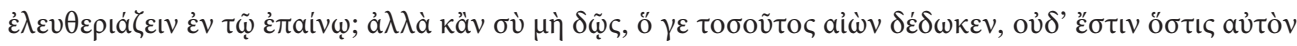

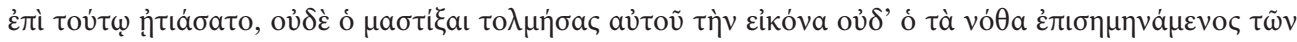
$\dot{\varepsilon} \pi \tilde{\omega} \nu \dot{\varepsilon} \nu \tau \tilde{n} \pi \alpha \rho \alpha \gamma \rho \alpha \varphi \underline{n} \tau \tilde{\omega} \nu$ ỏ $\beta \varepsilon \lambda \tilde{\omega} v$.

'If that was said, then would you hate even him (scil. Homer) and throw his book away, or would you let him speak freely in his praise? But if you did not let him, time itself let him, and there would be nobody who can charge him or dare whip his image, or label the spurious verses with the marginal sign of the obeloi.'

5 Blass (1874: p. 345); Lehrs (1882: p. 208); Jacoby (1926: p. 103) lent support to this hypothesis by considering similar compounds found in titles of polemical works, such as the Ciceromastix by Licinius (Gell. 17.1.1) or the Aeneidomastix by Carvilius (Ael.Don. Vit. Verg. 10), but the most recent critics have rejected it. See Apfel (1938: p. 250); Gärtner (1975: p. 1549; 1978: p. 1543); Matthaios (2009: p. 825); Williams (2013); Regali (2015); Goulet-Cazé (2018: p. 423). 
In this text, Panthea accuses Licinius of being a blasphemous flatterer because he compared her to goddesses like Hera and Aphrodite. The man defends his own behaviour by recalling Homer himself and especially $I l$. 19.282-286 - verses in which Briseis, a barbarian woman and slave, was compared to the golden Aphrodite and other goddesses.

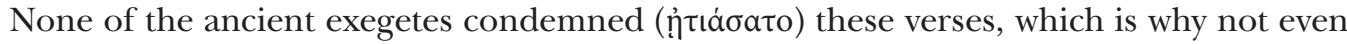
Panthea could condemn them. Here, Lucian mentions two different approaches to the Homeric text, the first exegetical and the second philological and strictly linked to the Alexandrian criticism of the text. These approaches are exemplified through two significant figures, who are not explicitly named but only mentioned via periphrases: ó

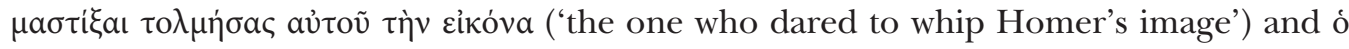

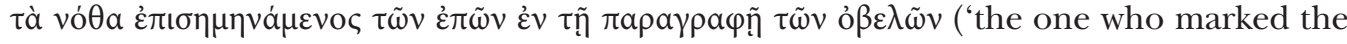
spurious verses through the obeloi'). Undoubtedly, these two periphrases respectively refer to Zoilus' Homeric criticism and to the Aristarchaean philology, which generalized the practice of athetesis (and the diacritical sign of the obelos) at the risk of expunction. However, the scholiast misunderstood and combined the two clearly distinct (oủ $\delta$... oủ $\delta$ ') figures, erroneously interpreting them as referring to Zenodotus alone - the first

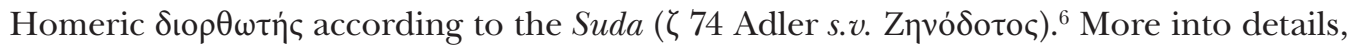
the scholium identifies in the Alexandrian practice of the athetesis the very 'whipping' of the poet, perhaps as it was influenced by Lucian's condemnation of such practice in the True History (2.20). In this passage, Homer, on the Island of the Blessed, was asked by the protagonist whether the verses athetized by the grammarians were original or not, and he replied that all the verses of his poems were authentic, defining the Alexandrian

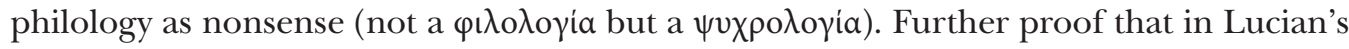

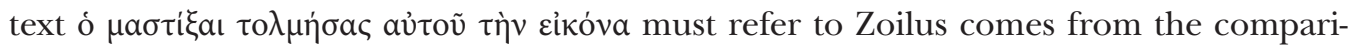
son with another passage from Galen's Methodus Medendi (1.3 = fr. 13 Friedländer $)$.

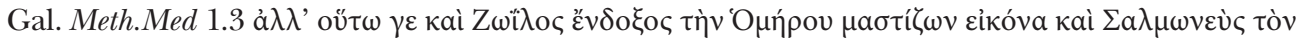

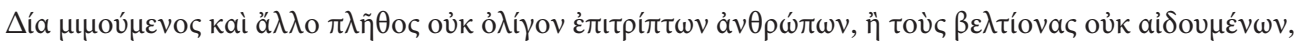

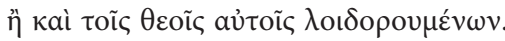

'In fact, Zoilus also became famous by whipping the image of Homer and Salmoneus, by imitating Zeus, and a not small number of scoundrels, who either do not honour the best, or slandered the gods themselves.'

In this passage, Galen speaks about sacrilege and ingratitude and compares the mythical figure of Salmoneus with Zoilus, who is famous for having whipped an image of Homer. Perhaps, these two testimonies allow us to hypothesize that in the 2nd century AD, an anecdote about the effective whipping of a Homeric image or statue by Zoilus flourished

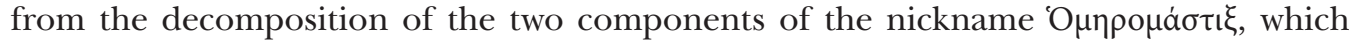
must be older since it is first attested to in our sources by Vitruvius.

6 For more on another confusion between Zoilus and Zenodotus, see schol. D Il. 5.4 ZYQAUIGeLe and Eust. Il. 2.3.13 Valk (FGrHist $71 \mathrm{~F}$ 7), where Zoilus is called "of Ephesus" (as Zenodotus). On the issue, see Friedländer (1895: p. 27, n. 6); Gärtner (1978: p. 1532); Regali (2015); Goulet-Cazé (2018: p. 422). 


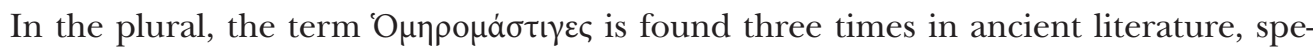
cifically in two passages from Eustathius and Pliny (Eust. Od. 1.301.29-31 Stallbaum, Od. 1.439.41-440.2 Stallbaum, Plin. NH 1 Praef. 28). Whereas in the Naturalis Historia, Homeromastiges is not associated with any polemical observation of Homeric passages and seems to allude generically to potential critics of Pliny's grammatical books, ${ }^{7}$ the other two passages from Eustathius' Commentaries on Homer's Odyssey seem to refer to precise criticisms of the Homeric text, under which specific personalities of grammarians are to be recognized. In both cases, however, no names of grammarians are explicitly mentioned. Considering that $\mathrm{O} \mu \eta \rho \mu^{\alpha} \sigma \tau \tau \xi \xi$ in the singular form is found exclusively in reference to Zoilus, it is legitimate to investigate whether it is possible to discern behind

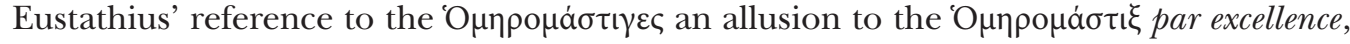
viz. Zoilus, or whether this epithet was used to allude generally to otherwise unidentified Homeric critics. The second passage was ascribed to Zoilus by Gärtner (1978:

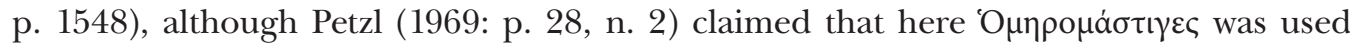
to indicate Homeric critics in general. The passage contains several points of criticism of the dialogue between Odysseus and Heracles in the Nekyia of Odyssey 11, which can be traced back to different periods and different grammarians (among whom also Aristarchus, see Schironi 2018: pp. 646, 677) - for the analysis of which see Petzl (1969: pp. 28-43). ${ }^{8}$ The object of the present analysis will be, instead, the first passage, from which we might draw interesting conclusions concerning the issue of the identification of the

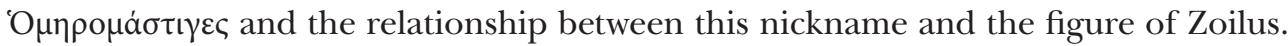

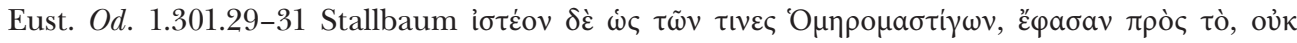

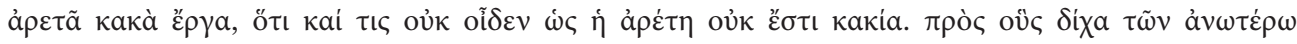

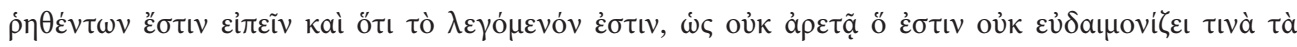
кakà है $\rho \gamma \alpha$.

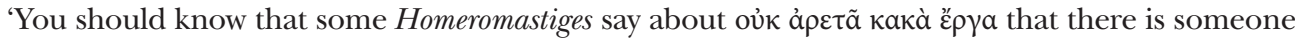

7 Plin. NH 1 Praef. 28 Ego plane meis adici posse multa confiteor, nec his solis, sed et omnibus quos edidi, ut obiter caveam istos Homeromastigas (ita enim verius dixerim), quoniam audio et Stoicos et dialecticos Epicureos que - nam de grammaticis semper expectavi - parturire adversus libellos, quos de grammatica edidi, et subinde abortus facere iam decem annis, cum celerius etiam elephanti pariant. 'For my own part I frankly confess that my works would admit a great deal of amplification, and not only those now in question but also all my publications, so that in passing I may insure myself against your "Scourges of Homer" (that would be the more correct term), as I am informed that both the Stoics and the Academy, and also the Epicureans - as for the philologists, I always expected it from them - are in travail with a reply to my publications on Philology, and for the last ten years have been having a series of miscarriages - for not even elephants take so long to bring their offspring to birth!' Translation from Rackham (1949: p. 19).

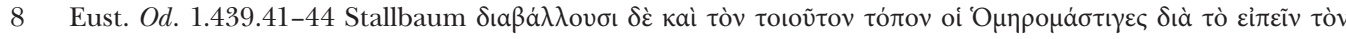

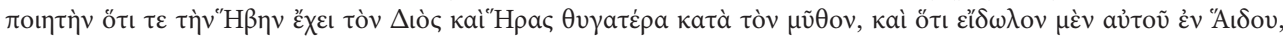

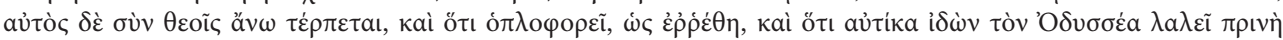

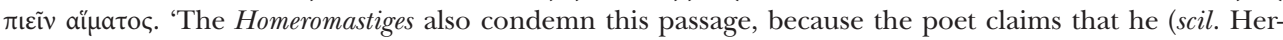
acles) married Hebe, the daughter of Zeus and Hera according to the myth, that his ghost is in Hades, but he lives blessed in heaven among the gods, that he wears weapons, as has been said, and that, as soon as he sees Odysseus, he starts talking without having first drunk the blood.' See also schol. Od. 11.568 TV (for which, see Petzl 1969: pp. 41-43), which refers anonymously to the zetemata, attributed by Eustathius to the Homeromastiges. 
who does not know that virtue does not correspond to vice. Against those, in addition to what

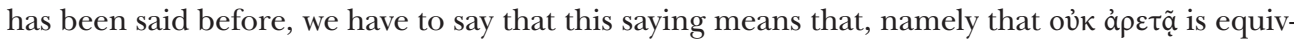
alent to "none of the bad habits brings happiness".'

Eustathius' passage comments on Demodocus' account of the adultery of Ares and Aphrodite. The gods comment on the vision of the chained lovers, Ares and Aphrodite, caught red-handed by Hephaestus, the betrayed husband. Two gnomic sentences open

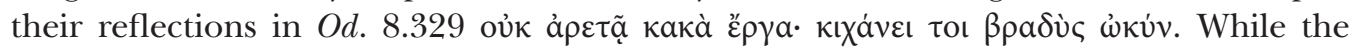
meaning of the second gnome is clear, "the slow catches the swift", referring to the capture of Ares by crippled Hephaestus, the meaning of the first is widely discussed in the scholiographic and scholarly tradition. The term ảpetã is now interpreted as a singular

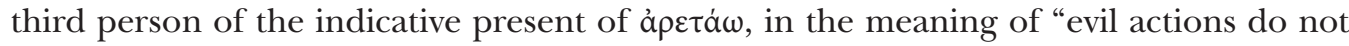
succeed", ${ }^{9}$ now as a singular dative of à $\rho \varepsilon \tau \dot{\alpha} /$ à $\rho \varepsilon \tau \dot{\eta}$, in the meaning of "evil actions do not bring (lead) to virtue (to virtuous behavior)/are not found in virtue". ${ }^{10}$ Eustathius him-

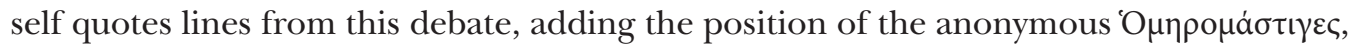
according to which there was someone who did not know that virtue did not correspond

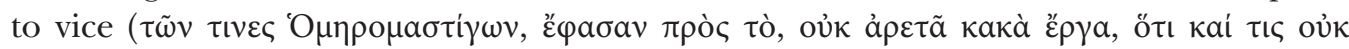

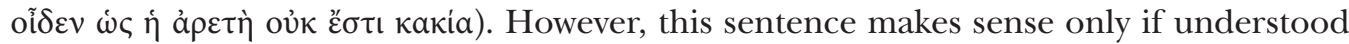

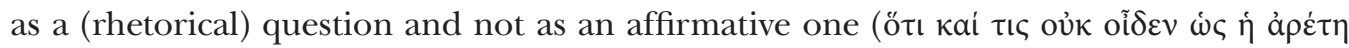

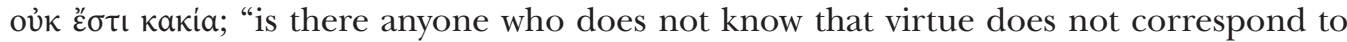

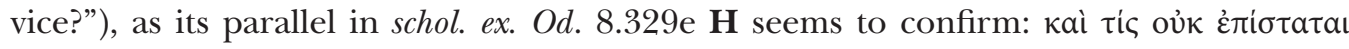

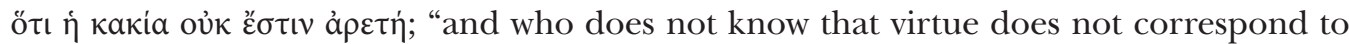

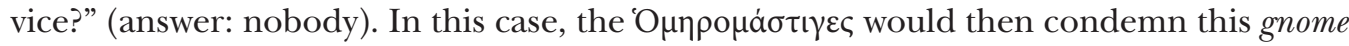
as obvious and self-evident. The prerequisite for such an interpretation, however, is the

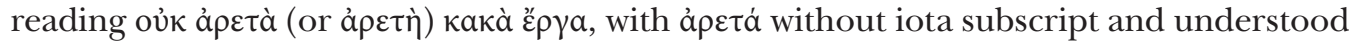
as a nominative - Doric perhaps - even though such a form never recurs in Homeric poetry. This varia lectio is, nevertheless, also attested to by the codex $\mathbf{U}$ (Monacensis Augustanus 519B) of the Odyssey, according to the apparatus of the Ludwich edition (1889: p. 179) and perhaps by the schol. ex. Od. 8.329g ${ }^{1}$ EHX, as Buttman (1821: p. 295 and ap.

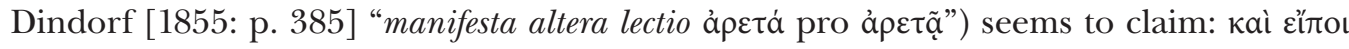

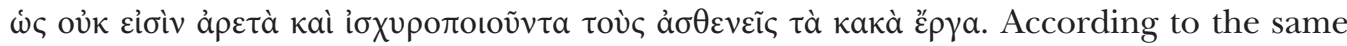
scholar, this variant could have also been transmitted by schol. ex. Od. 8.329e $\mathbf{H}$, as can be

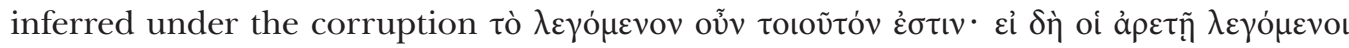

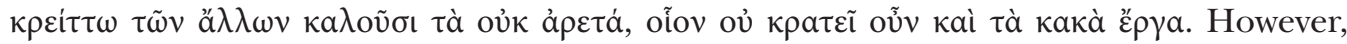
Pontani (2020: p. 162), the most recent editor of these scholia, suggests an emendation for both schol. ex. Od. 8.329g ${ }^{1}$ EHX and schol. ex. Od. 8.329e $\mathbf{H}$, in order to eliminate

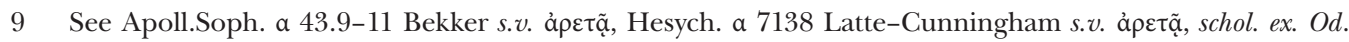
8.329a ${ }^{2}$ B, schol. ex. Od. 8.329b ${ }^{1}$ EX, schol. ex. Od. 8.329b ${ }^{2}$ EXs, schol. ex. Od. 8.329c T, schol. Hrd. Od. 8.329d ${ }^{1}$ H, schol. Hrd. Od. 8.329d ${ }^{2}$ EMaX, schol. V (Hrd.) Od. 8.329d ${ }^{3}$ HMaVYy, schol. V (Hdr.) Od. 8.329d ${ }^{4} \mathbf{X}$, Et.M. 138.44-49 Gaisford s.v. ảpetạ̃, [Zonar.] o 1485.23-27 Tittmann s.v. oủk ảpetạ̃, Eust. Od. 1599.29, 1.301.24 Stallbaum.

10 See Apoll.Soph. a 43.9-11 Bekker s.v. ảpetạ̃, schol. ex. Od. 8.329a ${ }^{1}$ HP, schol. ex. Od. 8.329a $\mathrm{a}^{2}$ BD, schol. ex. Od. 8.329c T. 


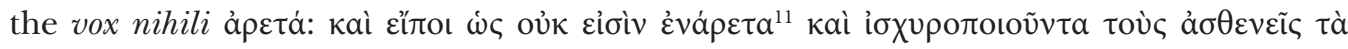

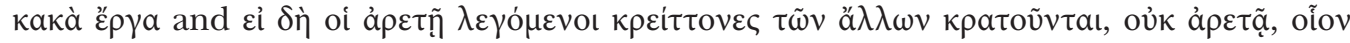
oủk ả not impossible: one of the two ancient interpretations of the form à $\rho \varepsilon \tau$ a , as has been already seen, actually implies a Doric form of dative, not found in Homer. In Eustathius' autographs (the Parisinus Graecus 2702 and the Marcianus Graecus 460) the reading

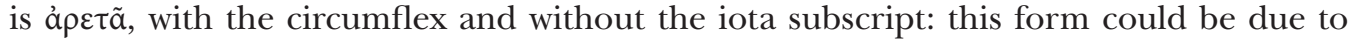

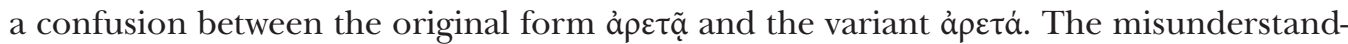

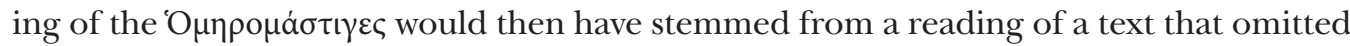
the iota in the improper diphthongs.

This condemnation is close to that of $I l$. 1.129, which was transmitted by the schol. Hdn. vel ex. Il. 1.129a A (FGrHist 71 F 6) and ascribed to Zoilus of Amphipolis (and the Stoic Chrysippus, who probably got it from Zoilus). Zoilus identified a solecism, or a syntactical incongruity, in the verb $\delta \tilde{\omega} \sigma \mathrm{r}-\mathrm{a}$ form that he understood as a plural, but

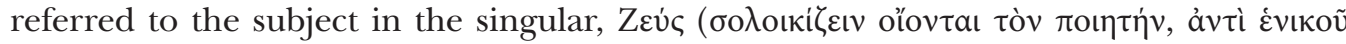

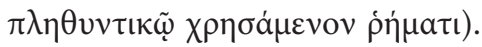

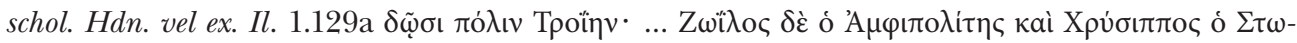

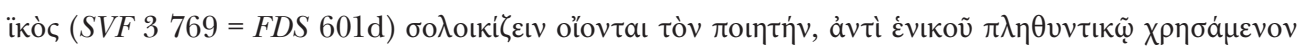

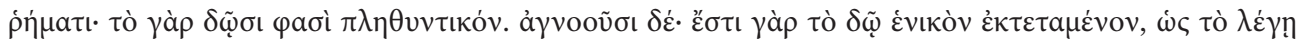

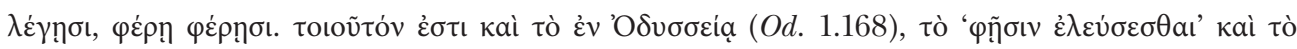

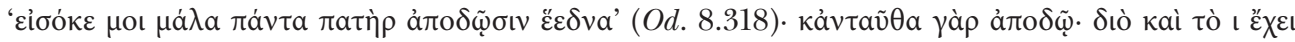
$\pi \rho о \sigma \kappa \varepsilon \dot{\mu} \varepsilon \varepsilon v o v . \mathbf{A}$

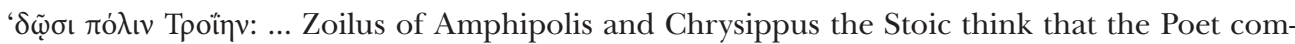
mitted solecism since he uses the verb in the plural and not in the singular. They understand then $\delta \tilde{\omega} \sigma ı$ as plural. But they were wrong. The singular $\delta \tilde{\omega}$ is lengthened, as $\lambda \dot{\varepsilon} \gamma \eta$ becomes $\lambda \dot{\varepsilon}$ -

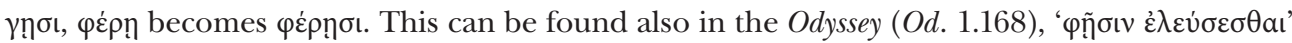

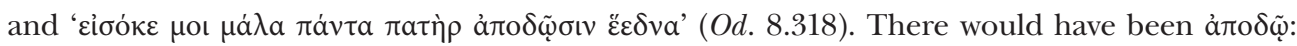
for that reason a $\iota$ is added.'

The context is that of $I l$. 1.127-129, where Achilles promises Agamemnon, who is forced to give back Chryseis, a compensation three or four times greater from the Achaeans if

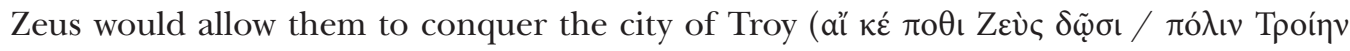

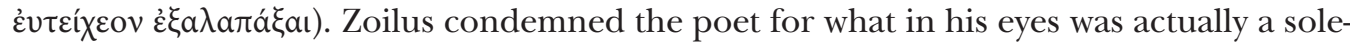
cism, because a subject in the singular form (Zev́c) was followed by a verb in the plural,

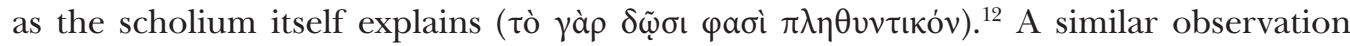
about a solecism in the Homeric poems can be found in a fragment by Protagoras

11 Évápetov is attested to in schol. ex. Od. 8.329b $\mathrm{b}^{1}$ EX and in Elias in Arist. categ. (CAG XVIII/1) 225.9 Busse.

12 This confusion is also attested to elsewhere, specifically in a lemma of the Lexicon by Apollonius the Sophist (61.15 Bekker s.v. $\delta \tilde{\omega} \sigma$ ) from the manuscript Coislinianus 345 (codex unicus for the lexicon), where

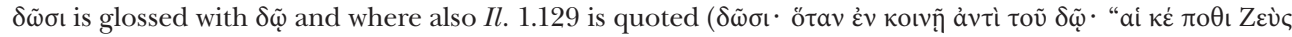
$\delta \omega \sigma \iota)$. 
(80 A 28 VS). ${ }^{13}$ However, in this fragment Protagoras merely observes that an apparently grammatically correct expression is in fact a solecism ( $\mu \tilde{\eta} v \iota v . . .0 v ่ \lambda o \mu \varepsilon \dot{v} \eta v$ in $I l .1 .1-2)$ and that, on the contrary, an apparently incorrect expression is not a solecism ( $\mu$ ñvı...

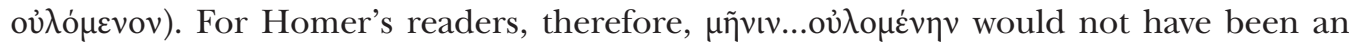

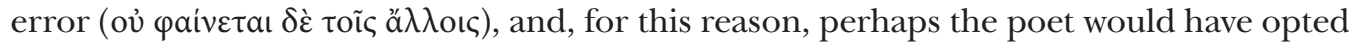
for this solution. If we hypothesize that Zoilus followed in the footsteps of Protagoras, it is possible to read Zoilus' remark in schol. Hdn. vel ex. Il. 1.129a A as a simple observation (and not a condemnation) about the apparent correctness of the expression Zev̀ $\delta \tilde{\omega} \sigma \mathrm{\sigma}$. The form $\delta \tilde{\omega} \sigma \mathrm{l}$, however, is correctly a singular third person of the subjunctive aorist of $\delta i \delta \omega \mu$ referring to Zeus, an epic form with a double ending. ${ }^{14}$ If, thus, we do not wish to admit that Zoilus failed to recognize this epic form (which occurs quite frequently in the text of the Homeric poems), we must assume that Zoilus read $\delta \tilde{\omega} \sigma \mathrm{l}$ without the iota subscript, that is a third plural person as most of the recent critics and many scholars seem to claim. ${ }^{15}$ Whether $\delta \tilde{\omega} \sigma \mathrm{\iota}$ was a true varia lectio, ${ }^{16}$ or a (wrong) form generated by confusion, it was the reading of the Homeric text consulted by Zoilus - that with which he took issue.

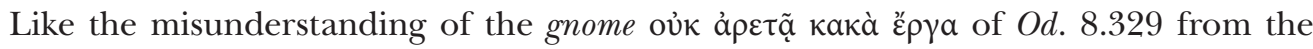

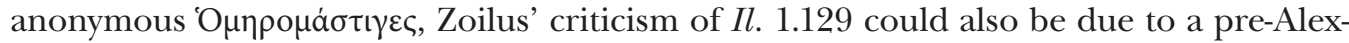
andrian copy that omitted the $\iota$ in the improper diphthongs. ${ }^{17}$ The two condemnations are, however, only apparently similar: in the case of $O d .8 .329$, a logical criticism (a tautology) is raised, whereas in the case of $I l$. 1.129 the culprit is a grammatical (or syntactical) error (a solecism). The affinity of the exegeses is likely not accidental, and, thus, it is

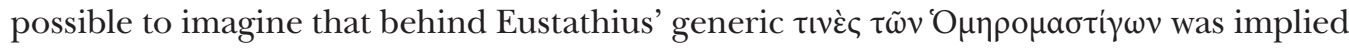
the most famous Homeromastix, Zoilus of Amphipolis. Zoilus was mentioned many times by Eustathius (Il. 2.3.13-29 Valk [fr. 27 Friedländer], Il. 4.970.3-15 Valk [FGrHist $71 \mathrm{~F}$ 17], Od. 1.321.44-322.1 Stallbaum [fr. 39 Friedländer]), who referred to him twice by his nickname (Il. 2.3.13-29 Valk, Od. 1.321.44-322.1 Stallbaum). It is, however, possible that here Eustathius not only hinted at Zoilus but also at other Homeric exegetes; this hypothesis would also explain the untypical plural. Nevertheless, the comparison between Eust. Od. 1.301.29-31 Stallbaum and schol. Hdn. vel ex. Il. 1.129a $\mathrm{a}^{1} \mathbf{A}$ is interesting, because even if it does not attest to an excerpt of Zoilus' Homeric exegesis (which must have been larger than what the sparse evidence of the scholiographic tradition reveals to

13 For more on the concept of solecism, see Flobert (1986); Pagani (2015: p. 804); Sandri (2020: pp. 15-49). Regarding the solecism in Protagoras, see Lougovaya \& Ast (2004).

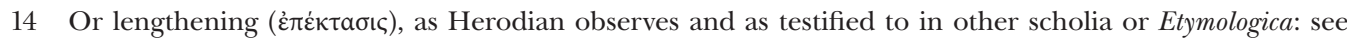

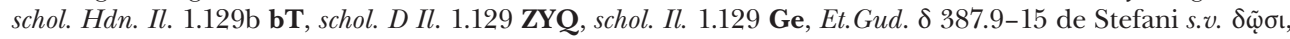

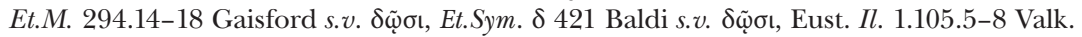

15 See Cobet (1876: pp. 261, 339); Ludwich (1884: p. 181); Friedländer (1895: p. 14); Leaf (1900: p. 14); Jacoby (1926: p. 111); Williams (2013).

16 Perhaps an older equivalent of $\delta \tilde{\omega} \sigma \mathrm{t}$, as West (1998: p. XXXI) thinks.

17 According to Cobet (1876: pp. 258-263, 339-342), this omission was common in pre-Alexandrine texts, as several indications in the Homeric scholia derived directly from the Aristarchaean exegesis seem to attest

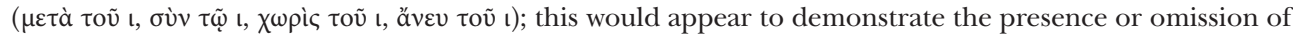
this grapheme in the copies available to the Alexandrian philologists. 
us), it does testify to a noteworthy similarity between the two exegeses, made even more

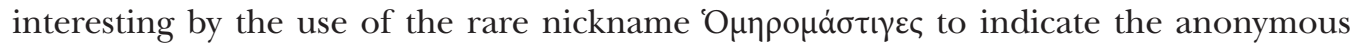
authors of the criticism of $\mathrm{Od}$. 8.329. In conclusion, at least one of the three occurrences

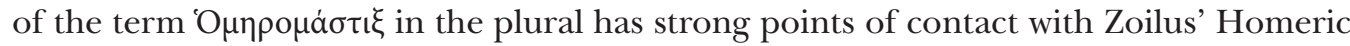
exegesis. Furthermore, as seen in the first part of the paper, the nickname in the singular form occurs exclusively referred to Zoilus. This analysis allows us to conclude that Zoilus has been seen as the Homeric detractor par excellence since antiquity. As a matter of fact, every criticism of Homer (or of other famous poets) after the 4th century BC as transmitted by the scholarly tradition (including the Homeric reworks of the imperial age, such as the Troikos of Dio Chrysostom) necessarily had to deal with Zoilus' work. ${ }^{18}$

\section{Bibliography}

\section{Primary Sources}

Adler, A. (Ed.). (1931). Suidae Lexicon (Vol. 2). Leipzig: Teubner.

Buttman, P. (Ed.). (1821). Scholia Antiqua in Homeri Odysseam. Berlin: in Libraria Myliana.

Dindorf, G. (Ed.). (1855). Scholia Graeca in Homeri Odysseam (Vol. I). Oxonii: e typographeo Academico.

Erbse, H. (Ed.). (1969). Scholia Graeca in Homeri Iliadem. Scholia Vetera, 1: Praefationem et scholia ad libros A- $\Delta$ continens. Berolini: De Gruyter.

Friedländer, U. (1895). De Zoilo aliisque Homeri obtrectatoribus. Königsberg: ex officina Leupoldiana. Jacoby, F. (Ed.). (1926). Die Fragmente der griechischen Historiker, 2/A: Zeitgeschichte, Universalgeschichte und Hellenika (nr. 64-105). Berlin: Weidmann.

Kühn, C. G. (Ed.). (1825). Claudii Galeni opera omnia (Vol. 10). Leipzig: Knobloch.

Leaf, W. (Ed.). (1900). The Iliad (Vol. 1). London: Cambridge University Press.

Longo, V. (Ed.). (1986). Dialoghi di Luciano (Vol. II). Torino: UTET.

Ludwich, A. (Ed.). (1889). Homeri Odyssea (Vol. 1). Leipzig: Teubner.

Pontani, F. (Ed.). (2020). Scholia Graeca in Odysseam, 4: Scholia ad libros $\eta-\theta$. Roma: Edizioni di Storia e Letteratura.

Rabe, H. (Ed.). (1906). Scholia in Lucianum. Leipzig: Teubner.

Rackham, H. (Transl.). (1949). Pliny. Natural History. Preface and Books 1-2. Cambridge (Mass.) London: Harvard University Press.

Stallbaum, G. (Ed.). (1825). Eustathii archiepiscopi Thessalonicensis commentarii ad Homeri Odysseam (Vol. 1). Leipzig: Weigel.

West, M. L. (Ed.). (1998). Homerus: Ilias (Vol. 1). Stuttgardiae - Lipsiae: Teubner.

Williams, M. F. (2013). Zoilos of Amphipolis (71). In I. Worthington (Ed.), Brill's New Jacoby [retrieved 20.03.2021 from http://dx.doi.org/10.1163/1873-5363_bnj_a71].

18 On the influence of Zoilus on detractors of Homer and of other poets, see Bishop (2015). Even among the modern critics, if the author of an ancient criticism against Homer has to be imagined, Zoilus himself is taken as a fictitious example: see Mayhew (2019: p. 57 «one can image Zoilus (or someone like him) criticizing Homer for...», see also o.c. pp. 81, 128). 


\section{Secondary Sources}

Apfel, H. V. (1938). Homeric Criticism in the Fourth Century B.C. Transactions and Proceedings of the American Philological Association, 69, 245-258.

Bishop, C. (2015). Hipparchus Among the Detractors? In C. S. Kraus, \& C. Stray (Eds.), Classical Commentaries: Explorations in a Scholarly Genre (pp. 379-395). Oxford: Oxford University Press.

Blass, F. (1874). Attische Beredsamkeit. Zweite Abteilung. Isokrates und Isaios. Hildesheim: Olms.

Bouchard, E. (2016). Du Lycée au Musée. Théorie poétique et critique littéraire à l'époque hellénistique. Paris: PU Paris-Sorbonne.

Cobet, C. G. (1876). Miscellanea critica quibus continentur observationes criticae in scriptores graecos praesertim Homerum et Demosthenem. Lugduni Batavorum: E. J. Brill.

Erbse, H. (1960). Beiträge zur Überlieferung der Iliasscholien. München: C. H. Beck.

Flobert, P. (1986). La théorie du solécisme dans l'antiquité: de la logique à la syntaxe. Revue de philologie, 60, 173-181.

Fraser, P. M. (1970). Aristophanes of Byzantion and Zoilus Homeromastix in Vitruvius. A Note on Vitruvius VII, Praef. 4-9. Eranos, 68, 115-122.

Gärtner, H. (1975). Zoilos (n. 4). In K. Ziegler et al (Eds.), Der kleine Pauly (Vol. 5; col. 1549-1550). München: Druckenmüller.

Gärtner, H. (1978). Zoilus (14). In A. F. Pauly et al. (Eds.), Paulys Realencyclopädie der classischen Altertumswissenschaft (Suppl. 15; col. 1531-1554). München: Druckenmüller.

Goulet-Cazé, M.-O. (2018). Zoïlos d'Amphipolis. In R. Goulet (Ed.), Dictionnaire des Philosophes Antiques. VII d'Ulpien à Zoticus (pp. 421-436). Paris: CNRS Éditions.

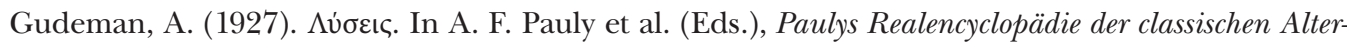
tumswissenschaft (Vol. 13; col. 2511-2518). Stuttgart: Metzler.

Heath, M. (2009). Heraclides of Pontus on Homer. In W. W. Fortenbaugh, \& E. Pender (Eds.), Heraclides of Pontus. Discussion (pp. 251-272). New Brunswick - London: Transaction Publishers.

Lehrs, K. $\left(1882^{3}, 1833^{1}\right)$. De Aristarchi studiis Homericis. Königsberg: apud S. Hirzelium.

Lougovaya, J., \& Ast, R. (2004). Menis and Pelex. Protagoras on Solecism. Classical Quarterly, 54(1), 274-331.

Ludwich, A. (1884). Aristarchs homerische Textkritik nach den Fragmenten des Didymos dargestellt und beurtheilt (Vol. 1). Leipzig: Teubner.

Matthaios, S. (2009). Zoilus (1). In H. Cancik, \& H. Schneider (Eds.), Brill's New Pauly (Vol. 15; col. 947). Leiden: Brill.

Mayhew, R. (2019). Aristotle's Lost Homeric Problems. Textual Studies. Oxford: Oxford University Press.

Novokhatko, A. (2015). Greek Scholarship from its Beginnings to Alexandria. In F. Montanari, S. Matthaios, \& A. Rengakos (Eds.), Brill's Companion to Ancient Greek Scholarship (Vol. 1; pp. 3-59). Leiden - Boston: Brill.

Novokhatko, A. (2020). Homeric Hermeneutics on the Way from Athens to Alexandria. In P. Finglass, A. Rengakos, \& B. Zimmermann (Eds.), More than Homer Knew - Studies on Homer and His Ancient Commentators (pp. 87-146). Berlin - New York: de Gruyter.

Pagani, L. (2015). Language Correctness (Hellenismos) and its Criteria. In F. Montanari, S. Matthaios, \& A. Rengakos (Eds.), Brill's Companion to Ancient Greek Scholarship (Vol. 2; pp. 798-849). Leiden - Boston: Brill. 
Pavlova, A. V. (2019). Arist. Poet. 1461b1-3: a Broad Hint at Zoilus? Philologia Classica, 14(1), 149-154.

Petzl, G. (1969). Antike Diskussionen über die beiden Nekyiai. Meisenheim: Hain.

Pfeiffer, R. (1968). History of Classical Scholarship from the Beginnings to the End of the Hellenistic Age. Oxford: Clarendon Press.

Pilch, S. (1924). De Zoilo Homeri obtrectatore. Eos, 27, 28.

Regali, M. (2015). Zoilus [1]. In Lexicon of Greek Grammarians of Antiquity [retrieved 21.03.2021 from http://dx.doi.org/10.1163/2451-9278_Zoilus_1].

Sandri, M. G. (2020). Trattati greci su barbarismo e solecismo. Introduzione ed edizione critica. Berlin Boston: de Gruyter.

Schironi, F. (2018). The Best of the Grammarians: Aristarchus of Samothrace on the Iliad. Ann Arbor: University of Michigan Press.

Weiß, P. (2019). Tod eines Kritikers: Zur Zoilosanekdote bei Vitruv 7. praef. 8-9 und ihrem Nachleben in den Saturnalia des Macrobius. In G. Bitto, \& A. Ginestí Rosell (Eds.), Philologie auf zweiter Stufe. Literarische Rezeptionen und Inszenierungen hellenistischer Gelehrsamkeit (pp. 119-132). Stuttgart: Franz Steiner Verlag.

Marta Fogagnolo / marta.fogagnolo@fileli.unipi.it

Department of Philology, Literature and Linguistics

University of Pisa

Palazzo Venera - Via Santa Maria, 36, 56126 Pisa, Italy 
